\title{
EDUCATION POLICY AND HISTORY EDUCATION AS TOOLS FOR SHAPING AN OPEN SOCIETY IN POLAND: A CRITICAL ANTHROPOLOGICAL ANALYSIS
}

\begin{abstract}
The aim of this article is to examine the education policy in modern Poland from the anthropological point of view. We will begin with the assumption that education policy is the outcome of social, cultural, economic and political circumstances that influence both the vision of education at a given time, as well as its specific goals. Then we will present modern educational discourses from the perspective of socio-cultural anthropology as a cultural criticism and an essential part of new interventional humanities. The main purpose of this article is to address whether modern education policy, and above all history education in Poland, can be used as a tool to shape an open society as understood by Karl Popper. We will also demonstrate how official education discourse in Poland highlights patriotic and even nationalist issues, while silencing socio-cultural values and practices that constitute the foundation of democracy and open society.
\end{abstract}

Key words: socio-cultural anthropology; education policy; history education; core curriculum; open society; Karl Popper
KATARZYNA MAJBRODA Uniwersytet Wrocławski, Wrocław E-mail: katarzyna.majbroda@uwr.edu.pl

CITATION: Majbroda, K. (2018). Education Policy and History Education as Tools for Shaping an Open Society in Poland: a Critical Anthropological Analysis. Sprawy Narodowościowe. Seria nowa, 2018(50). https://doi.org/10.11649/sn.1646

This work was supported by the National Science Centre (grant number UMO-2012/06/A/HS3/ 00266). No competing interests have been declared.

This is an Open Access article distributed under the terms of the Creative Commons Attribution 3.0 PL License (creativecommons.org/licenses/by/3.0/pl/), which permits redistribution, commercial and non-commercial, provided that the article is properly cited. (C) The Author(s) 2018.

Publisher: Institute of Slavic Studies, Polish Academy of Sciences 


\section{WSPÓLCZESNA POLITYKA EDUKACYJNA I NAUCZANIE HISTORII W POLSCE JAKO NARZĘDZIA KSZTALTOWANIA SPOLECZEŃSTWA OTWARTEGO. KRYTYCZNA ANALIZA ANTROPOLOGICZNA}

\section{Streszczenie}

Celem artykułu jest pokazanie współczesnej polityki edukacyjnej funkcjonującej w Polsce w perspektywie antropologii społeczno-kulturowej. Punktem wyjścia jest założenie, iż polityka edukacyjna jest wynikiem splotu czynników społecznych, kulturowych, ekonomicznych oraz politycznych, które wpływają zarówno na obowiązującą w określonym czasie wizję edukacji jako takiej, jak i na jej cele szczegółowe. Tekst pokazuje współczesne dyskursy edukacyjne w perspektywie antropologii spoteczno-kulturowej widzianej jako krytyka kulturowa i istotna część nowej humanistyki o charakterze interwencyjnym. W tym kontekście głównym wątkiem spajającym niniejszy artykuł jest pytanie o to, czy współczesna polityka edukacyjna a przede wszystkim edukacja historyczna w Polsce stanowią narzędzia kształtowania społeczeństwa otwartego w rozumieniu Karla Poppera. Istotnym aspektem tekstu jest pokazanie rozwijanego w Polsce oficjalnego dyskursu edukacyjnego, który eksponuje wątki patriotyczne, a nawet nacjonalistyczne, wyciszając wartości i praktyki społeczno-kulturowe, będące fundamentem demokracji i społeczeństwa otwartego.

Słowa kluczowe: antropologia społeczno-kulturowa; polityka edukacyjna; edukacja historyczna; podstawa programowa; spoleczeństwo otwarte' Karl Popper

\footnotetext{
$\mathrm{T}$
} his study aims to analyze modern Polish educational policy from the anthropological point of view. We will focus on two issues that seem especially important in determining whether modern history education is a space for shaping an open society.

These considerations are based on two presuppositions. The first is that education is the most important tool for shaping a society; and that it is a space for reproducing and transmitting the values, principles and norms that define and regulate socio-cultural practices. I share the opinion of Jeremy Bruner, who stressed that "an educational undertaking that avoids the inevitable risk related to developing and promoting a certain vision of the world is at risk of stagnation and ultimately-alienation" (Bruner, 2006, p. 31).

The second is the role of socio-cultural anthropology within the humanities, i.e. its potential to diagnose, explain and intervene in socio-cultural phenomena. It should be able to critically analyze the mechanisms and strategies for describing these phenomena, and attempt to explain their cultural, social, political and economic causes.

\section{SOCIO-CULTURAL ANTHROPOLOGY AS THE HUMANITIES IN ACTION}

For several decades, cultural anthropology has been at the center of the humanities, where it has done much to reorient human disciplines towards culture (Kaniowska, 2009; Majbroda, 2011; Markowski \& Nycz, 2012; Piasek, 2011). Today, it strengthens the position of the "new" humanities, an interventional discipline that aims to support marginalized and subordinate groups by promoting bottom-up representations and silenced sociocultural issues. This is addressed by George Marcus and Michel Fischer, who perceive anthropology as a repatriation of cultural criticism, stressing that "the strength of ethnog- 
raphy and ethnographic criticism is their focus on detail, their enduring respect for context in the making of any generalization, and their full recognition of persistent ambiguity and multiple possibilities in any situation" (Marcus \& Fischer, 1999, p. 159). Such aims are also classified as assumptions of the performative humanities, which do not interpret, but instead attempt to influence the world with their theories and stimulate social entities to action. They are the vanguard of the humanities, in which studying is not an "art for art's sake." In other words, "they are not a way of contemplating or admiring the world, but mainly a tool for understanding and analyzing the world for the purpose of influencing and generating change" (Domańska, 2007, p. 55).

Cultural anthropology as the humanities in operation is also part of the new humanities trend, which has great subversive and emancipating potential, and does not measure results only within professional academic study. As stressed by Ryszard Nycz (2015), it also fulfills important social functions and plays important cultural roles, as it is a type of intervention in the "area of social awareness, unconsciousness and the symbolic universe of culture, norms, attitudes and behaviors" (Nycz, 2015, p. 17). Such anthropology enacts the new humanities through empirical studies (Červinková \& Gołębniak, 2010).

An obvious and basic aspect of anthropological research is action, which is defined by Peter Reason and William Torbert (Reason \& Torbert, 2010) as an addition to earlier narratives within the historical and pedagogical sciences, as well as a context for the generation of extended epistemology, characterized by the co-existence of approaches and scientific categories developed within the methodology of qualitative research. Put simply, as part of this trend, anthropological studies are treated as a scientific practice aimed at highlighting and identifying current socio-cultural practices and phenomena. One of these is the development of specific education policy.

Anthropology practiced as such is also consistent with the aims outlined by Leela Ghandi for opposing critical discourse, who stressed that its role is to object to "the exclusions of humanist thought" (Ghandi, 2008, p. 53); as well as to increase the representativeness of this area of knowledge. The goals of critical discourse are focused on "disclosing interests that are present in the knowledge-generation process," and on the attempt to recover "illegal, disqualified or subordinate systems of knowledge" (Ghandi, 2008, p. 53).

\section{FROM EDUCATION TO DEMOCRACY AND BACK}

As claimed by Jacques Derrida in his essay-lecture, Uniwersytet bezwarunkowy,

A university should be a place where nothing can block the force of inquiry; not even what is currently believed to be a specific figure of democracy. Subject to inquiry should be the classic idea of criticism, i.e. theoretical criticism, and even the authority of inquiring or thinking as inquiring. (Derrida, 2015, p. 13)

Education and democracy are inseparably connected with thought and social practice. Education as an important component of social life is especially susceptible to the changing social and economic climate. It is also not free from the influence of specific practices and political decisions that can be analyzed and interpreted from the anthropological perspective. Since the 1960s, anthropologists studying educational space have focused on uncovering specific cultural messages generated and transmitted through the education process, together with related practices (Levinson, Foley \& Holland, 1996). 
This corresponds with an observation by George Spindler (considered to be the founder of educational anthropology), who persuaded further generations of anthropologists to study educational space, stressing that schools are the main institutions for creating and reconstructing culture in statu nascendi (Spindler, 1974; Spindler \& Spindler, 1987). The anthropological analysis therein of education systems and their role in forming specific societies was based on the belief that the subjectivities of people are not formed naturally, and instead are the effect of specific discourses.

Paradoxically, education is both the cause and effect of our activity within a specific vision of culture and society. It is expected to be a breeding ground for democratic and civic society, and a space for the socialization and enculturation of individuals who consciously participate in its structures, know their rights and obligations, and have the ability to critically study their reality, as well as a sense of agency in various aspects of life (Archer, 2000).

In this context, I believe that we should question whether modern educational policy helps create an open society, which-according to Karl Popper-is a society founded on freedom, tolerance and human dignity in which individuals have the right to make personal decisions. It also empowers individuals to change their position in the social hierarchy (Popper, 1993). Furthermore, an open society assumes the empathic and respectful ability of its citizens to cope with otherness. Education founded on the core assumptions of an open society should be a strong socio-cultural strategy for counteracting the ideology of closedness. For Popper, the most explicit embodiments of closedness are totalitarian systems that subordinate the interests and expectations of individuals to national unity. The essence of an open society is a democracy that does not exhaust the semantic scope of Popper's vision of openness. It should be stressed that the establishment and functioning of an open society is not determined by the current political system, but by the values, attitudes and socio-cultural practices accepted by those who are intellectual leaders thanks in large part to education.

\section{EDUCATION AS SPACE FOR GENERATING ACCEPTED VALUES AND ATTITUDES}

From the anthropological viewpoint, education policy can be understood as a set of institutionalized discourses and practices outlining the goals, strategies and pragmatic scope of teaching, and which shape the imagination of the role and place of education in social life (Majbroda, 2016). By "modern education policy," we mean the social, political and cultural process that has been observed in the West since the end of World War II, in Western Europe since the 1960s and 70s, and in Poland since 1989 (See Frączak, 2004).

One of the foundations of modern European education, including education in Poland, is a Unesco report from 1994 prepared by the International $21^{\text {st }}$ Century Education Committee led by Jacques Delors, entitled, Edukacja: jest w niej ukryty skarb. The report claims that "education should transmit effectively and on an increasingly large scale the knowledge and skills evolving according to cognitive civilization, as these are the basis of competence of tomorrow." 1 This report formulates the four basic pillars of modern Euro-

-....

"Learning in order to be" is a reference to an earlier project of Edgar Faure from 1972, which in the preamble expressed a fear of global dehumanization, as well as the $21^{\text {st }}$ century as a time of media domination. Jacque Delores' report is based on humanistic ideas, and envisions the future of education as a process that transgresses institutional norms. 
pean education: "learn to know, that is, obtain the tools of understanding; act to impact your environment; learn to live and co-operate with others at all planes of human activity; and finally, learn in order to be" (See Wolter, 2016).

These pillars are thoroughly humanistic since they refer to the principal cultural values of Europe; but reference thereto in the context of further reform of the Bologna Process shows that they have been used to implement a neoliberal policy in European education (Kraśniewski, 2009). In Poland, as in other European countries, the Bologna Process, despite focusing mainly on higher education, has brought its discourse and corresponding praxis into the sphere of common education. This has fueled the imaginations of experts responsible for creating curricula and teaching materials for education at lower levels, and modelled state education policy to support the innovativeness and competitiveness of a globally significant, European country. ${ }^{2}$ Neoliberalism and its repercussions for education is an issue that deserves separate discussion. We will limit ourselves here to the fact that a qualitative analysis of the curricula, textbooks and ministerial documents that shape formal Polish education clearly indicates the expansion of neoliberal thought based on free-market rationality, which in turn is based on generalization of the homo economicus model for all forms of behavior that necessitate extension of economic analysis to domains previously considered non-economical (Michałowska, 2013).

Education is a basic instrument for the formation and stabilization of democracy, should be open and independent from its contextual circumstances and is essential to forming the accepted social order. The education system communicates and preserves specific visions of reality and methods for their valorization, preferring one at the cost of the others. As noted by Peter Lee, in the educational process of forming national identity:

History is very peculiar form of memory. To see this, we might compare the place forgetting plays in memory (collective or personal) and in history. Forgetting is essential to memory: it allows us to make memories perform the multitude of functions they perform in our lives. [...] Selection for any particular historical work involves ruling some things as relevant and others thereby irrelevant (as does answering any question whatsoever), but history is not the same as single stories, nor is it the property of any person or group, and what is marginal to one question is central to another. (Lee, 2011, p. xi)

From the anthropological point of view, education is the important process of producing critically thinking subjects of socio-cultural life, who consciously and contemplatively co-create social, cultural, economic and political phenomena by identifying them and consciously valorizing their position and role in the historical process. Organization of education entails exposition of certain content, and positive valorization of specific attitudes and values, while silencing and ignoring others. Preambuta podstawy programowej kształcenia ogólnego dla szkoły podstawowej stresses that:

The educational activity of a school is one of the basic goals of state education policy. Educating the young generation is to be done by the family and schools, which in their operation must consider the will of parents and the state, whose responsibility it is to create the proper conditions for education. Schools must orient the education process towards the values that determine its goals and the criteria for their assessment. [...] In the educational process, schools promote things and places important for the preservation of national memory, figures and events from the past, as well as major national holidays and state symbols. (Podstawa programowa kształcenia ogólnego z komentarzem. Szkoła podstawowa. Historia3, 2017, p. 9)

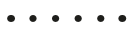

2 Let us recall that the meeting of the European Council in Lisbon in March 2000 assumed the strategic goal of "creating in Europe the most dynamic and globally competitive economy based on knowledge that ensures sustained development characterized by improved employment conditions and social harmony."

3 Basic Program of General Education with Comments. Primary School. History. 
For many years, an important goal of Polish education policy has been the education of citizens in patriotism, which is promoted by the study of subjects of national interest (Osiński, 2012), as well as nationalistic interest (Jaskułowski, Majewski, \& Surmiak, 2018). Researchers of the socio-cultural contexts of education profiles turn their attention to the lack of equality issues addressed by the curricula, which makes citizens indifferent to various types of otherness (Chrzanowska, Jachimczak \& Pawelczak, 2013). The history of Poland, just like that of every other country, is a configuration of national, ethical, religious and gender otherness and familiarity. Exposing only what is familiar, local and national, while silencing what is foreign and marginal seems artificial.

The exposition of knowledge on national culture and tradition observed in Polish curricula and teaching programs is similar to that observed in other countries (Carretero, 2011). We should note that this may strengthen the mechanism for generating and disseminating beliefs and attitudes focused on cultivating exclusive, essentialist values; as they are xenophobic and exclude certain groups and individuals based on their characteristics. A ministerial brochure entitled, Dobra szkoła. Reforma edukacji (2017) reads: "We want each of our graduates to praise their mother language and culture, in their entire heritage".(Dobra szkoła. Reforma edukacji. Najważniejsze zmiany. Pytania i odpowiedzi", 2017, p. 7). Similar are the general educational goals formulated in the Preambuła podstawy programowej kształcenia ogólnego dla szkoły podstawowej, according to which:

Training and education at the level of primary school contributes to the development of civic, patriotic and social attitudes in students. Schools should strengthen national identity, as well as attachment to history and national traditions, and prepare and encourage students to promote their schools and local environments, including by engaging in voluntary service. (Podstawa programowa kształcenia ogólnego z komentarzem. Szkoła podstawowa. Historia, 2017, p. 7)

Some concern may be aroused by one of the educational goals mentioned in Podstawa programowa do nauczania geografii, according to which:

\begin{abstract}
Geography is a great opportunity for patriotic education. It contains an essential reference to various spaces (home, city, region, country) and times (past, present, future). The important task of school geography in shaping patriotic attitudes and Polish pride should be executed via didactic activities that impart reliable knowledge on the natural and cultural heritage of Poland, as well as its place in Europe and the world. Awareness of our own value and roots, as well as the geography of our own regions and home country is the modern foundation for understanding other nations and cultures, without fearing loss of our own identity. (Podstawa programowa ksztatcenia ogólnego z komentarzem. Geografia5, 2017, p. 10)
\end{abstract}

This quote shows that the patriotic subjects of interest in Polish historical education are also present in geography, and strengthen negative and fearful social attitudes towards otherness, as it is unclear why learning the history and cultural heritage of Europe would threaten Polish identity.

There is no need here to quote long passages from the basic curricula for historical education, Polish-language education or ethics that highlight the importance of education in the spirit of patriotism, or attachment to national traditions. However, it is worth noting an inadvertent reference in the curriculum to European heritage, as well as the phenomenon of multiculturalism and diversity in daily social and cultural reality, includ-

- $\bullet$

4 Good Schools. Education Reform. The Most Important Changes. Questions and Answers.

5 Basic Program of General Education with Comments. Geography. 
ing in Poland. Further curricula for imparting knowledge of society-aimed at developing students' skills-assumes that students will be educated on "the national and ethnic minorities living in Poland, groups who use the regional language and groups of migrants (including refugees), including their place of habitual residence. It also determines in accordance with the Constitution the rights to which those ethnic minority groups are entitled" (Podstawa programowa kształcenia ogólnego z komentarzem. Szkoła podstawowa. Wiedza o społeczeństwie ${ }^{6}, 2017$, p. 14). Formulated as such, the aim of education is the specific ability to identify ethnic monitories, and the deictic ability to indicate their areas of residence on a map. We will not discuss the educational attempt to learn about and get accustomed to the cultures of these minorities by showing their traditions, customs, processes of transmitting value systems and cultural praxis. But from the viewpoint of social and cultural anthropology, education on the natural co-existence of various ethnic and national groups is essential for the elimination of prejudice, xenophobia and fear of otherness, and is thus the basis for creating a democratic and open society. That school textbooks contain information on social, political and cultural phenomena which reflect natural diversity seems to be very important.

The anthropologic postulate to include issues in formal education that would allow for a cognitive and imaginative understanding of the world beyond "what is Polish" is key, assuming that the material in school textbooks should develop a civic sensibility to prevent ill-conceived patriotism that contributes to xenophobic and homophobic attitudes. On the contrary, it is often used to stimulate hatred and violence towards specific ethnicities, religions, genders or worldviews (Wiśniewski, Hansen, \& Bilewicz, 2017). Education policy that does not take into account the risk of the above attitudes and practices contributes to the formation of a closed society. The goal of the European education-and thus Polish education-should be to develop the social, cultural and political instruments and strategies for counteracting closedness.

One of the mechanisms protecting society against the threat of isolation and loss of openness is global and European intercultural education. In Polish discourse on education after 1989, this issue is usually addressed only marginally (Abramowicz, 2011; Chustecka, Kielak, \& Rawłuszko, 2016). In 2003, Poland signed The Declaration of European Education Ministers on Intercultural Education in the New European Context, which officially made intercultural education a part of state policy (Deklaracja europejskich ministrów edukacji na temat edukacji międzykulturowej w nowym kontekście europejskim, n.d.). This document clearly stresses that European societies are diversified in terms of ethnicity, culture, language and religion; accounts for the social conflicts and divergences which may result from the coexistence of different value systems and declares a willingness to preserve the multi-cultural character of European society. It clearly expresses the need to develop strategies and instruments for multi-cultural education, curricula and didactic aids to prepare teachers to cope with new phenomena in schools related to discrimination, racism, xenophobia, sexism and the marginalization of individuals and social groups due to ethnic origin or economic status. This list should be expanded to cover phenomena related to migration and the refugee crisis.

"Knowledge of Culture," a subject from the basic 2012 curriculum, expanded students' knowledge of literature, music and art. It conveyed knowledge on high culture, and minorities were addressed only marginally (Majbroda, 2016). The latest curriculum from 2017 neither includes this subject, nor offers any elements of intercultural education

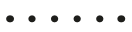

6 Basic Program of General Education with Comments. Primary School. Knowledge of Society. 
in history or other humanistic subjects (Podstawa programowa kształcenia ogólnego 2017). Moreover, Polish schools still use textbooks that often perpetuate stereotypes of various ethnic, national and religious groups. They convey schematic, prejudice-based visions of reality, as well as a fear of otherness, and ignore the coexistence of majority and minority groups in favor of the dominant culture ${ }^{8}$ (Chomczyńska-Rubacha, 2011).

\section{CURRICULUM AND TEACHING PROGRAM FOR EDUCATION IN PATRIOTISM AND NATIONAL IDEAS}

The Polish educational curriculum—as an official, ministerial document defining the basic aspects of state education policy-is also the starting point of the curricula for individual subjects at different levels of education. These in turn are perceived as a kind of outline that gives teachers a certain freedom with regard to teaching materials and methods. For education in history, the curriculum clearly accentuates competences that allow students to participate creatively and intentionally in the interpretation, understanding and diagnosis of the past. The 2012 Core Curriculum distinguishes three areas of historical study: historical chronology; historical analysis and interpretation and creation of historical narration. These skills are considered essential to conscious and critical historical education, and are intended to achieve the following educational goals: "the ability to criticize past and modern messages, and rationally define our own behaviors and attitudes; acceptance of cultural diversity; tolerance and openness towards the beliefs of other people and the will to solve conflicts peacefully and reasonably." (Podstawa programowa z komentarzami. T. 4. Edukacja historyczna i obywatelska w szkole podstawowej, gimnazjum i liceum? 2012, p. 30)

In the 2017 Core Curriculum, the goals of historical education in these three areas accentuate the pragmatic aspect of historical interpretation and creation of our own narratives of the past. (See Podstawa programowa ksztatcenia ogólnego z komentarzem. Szkoła podstawowa. Historia, 2017, p. 11.) The most important educational goals are seen as teaching patriotism and national identity. As stated in the document:

The pride we feel towards the achievements of our ancestors should not transform into a senseless apology, and criticism does not have to result in abandonment of the collective national effort that makes us Poles in the heart of Europe. Throughout the course of history, the following values have developed naturally: homeland, nation, state, national and state symbols, patriotism, historical memory, truth, justice, good, beauty, freedom, solidarity, responsibility, courage, criticism, tolerance, identity and culture. (Podstawa programowa kształcenia ogólnego z komentarzem. Szkoła podstawowa. Historia, 2017, p. 10.)

Basic Program of General Education.

8 Critical anthropological and sociological analysis of school history textbooks is one of the key elements of the grant, Wizje narodu w polskich podręcznikach do nauki historii-porównawcze badania antropologiczne (Visions of a Nation in Polish History Textbooks: a Comparative Anthropological Study). My analysis of textbooks used in Polish education since the 1990s clearly shows that women appear in them only incidentally, most often in stereotypical roles and areas that silence the activity of women and their real impact on political events, customs and cultures. Ethnic, national and religious minorities are usually described in narratives preserving their essentialized, stereotypical images. This is particularly clear in the affirmation of the history and culture of Poland, as well as in the conception that it has been a tolerant and multicultural place for many centuries, which is part of the discursive strategy to silence the real political and socio-cultural processes of various interest groups.

9 Basic Program with Comments. Vol. 4. Education in History and Citizenship in Primary School, Middle School, and High School. 
The history of the homeland is filled with pride, valor, heroism and the everyday hardship of our ancestors; but also tragedy, doubt and even villainy. We all should know the baggage of past times. (Podstawa programowa kształcenia ogólnego z komentarzem. Szkoła podstawowa. Historia, 2017, p. 10)

It is important to foster a belief that the future cannot be built without historical memory, respect for national heritage or a sense of care for historical monuments and memorabilia. (Podstawa programowa kształcenia ogólnego z komentarzem. Szkoła podstawowa. Historia, 2017, p. 10)

These objectives are expanded upon in detail in individual history curricula developed by the leading domestic educational publishing houses, whose history textbooks comply with the abovementioned document. As one curriculum from 2017 clearly states, "upon completion of history education in primary school, students [...] should exhibit a patriotic attitude; know and respect the history and traditions of their nation and other nations; have an attachment to their region and country; appreciate the values of Mediterranean civilization, i.e. love, truth, freedom, beauty, democracy, and respect for others regardless of their race, nationality or religion" (Plumińska-Mieloch, 2017, p. 3). This curriculum reveals the strategies of patriotic education that are very popular in various European countries-especially in preschool, when the first civic attitudes are formed. As believed by Mario Carretero in his book Constructing Patriotism: Teaching History and Memories in Global Worlds (2011):

When humanistic education takes on a patriotic form, history constitutes a crucial space for the transmission of values at school. In most countries, this happens at the beginning of the twentieth century and is reflected in the incorporation of national history as mandatory content at every educational level, with a special emphasis on early schooling cycles. (Carretero, 2011, p. 10)

History textbooks and the core curricula on which they are based offer competing narrations of history, tradition and socio-cultural heritage. This can clearly be seen when analyzing the method by which two further basic programs for teaching history shape students' knowledge on Poland's membership in the European Community. The 2017 History Core Curriculum - to a lesser extent than its counterpart from 2012—stresses the importance of students' knowledge of Poland's role in the European Union. There are only two references to the EU in the entire document, stating that students "shall be familiar with the goals and major stages of EU development" (Podstawa programowa ksztatcenia ogólnego z komentarzem. Szkoła podstawowa. Historia, 2017, p. 20) "[and] explain the causes and significance of Poland's accession to the European Union in 2004" (Podstawa programowa kształcenia ogólnego z komentarzem. Szkoła podstawowa. Historia, 2017, p. 21). The 2012 Core Curriculum assumes that students are familiar with the European Community; can explain Poland's membership to the European Community using the core concepts of the European Union, European solidarity and international relations; can identify the EU flag and anthem (Ode to Joy) (Podstawa programowa kształcenia ogólnego z komentarzem. Szkoła podstawowa. Historia, 2017, p. 30) and "are familiar with the goals and major stages of EU development (Podstawa programowa z komentarzami. T. 4. Edukacja historyczna i obywatelska w szkole podstawowej, gimnazjum i liceum, 2012, p. 46). The previous core curriculum also detailed two areas of EU knowledge. The first is European integration, in which students shall: 
1) be familiar with the goals and stages of European integration (Romanian Treaties, Maastricht Treaty, Treaty of Nice, Lisbon Treaty); 2) be able to explain the role and function of major EU institutions (European Council, Council of the European Union, European Parliament, European Commission); 3) be able to explain how the principles of subsidiarity and solidarity are realized in the European Union; 4) be able to explain the source of EU budget funds and how they are spent; 5) be able to indicate EU member states on a map, and justify their opinion on further integration and expansion. (Podstawa programowa kształcenia ogólnego z komentarzem. Szkoła podstawowa. Historia, 2017, p. 90)

The second is Poland in the European Union, in which students shall:

1) be familiar with the rights and obligations of being a citizen of the European Union; 2) be familiar with how European funds are used by Polish citizens, businesses and institutions; 3) be able to formulate and justify their own opinions on the benefits of being an EU member state with reference to examples from their own environment and the country as a whole. (Podstawa programowa kształcenia ogólnego z komentarzem. Szkoła podstawowa. Historia, 2017, p. 90)

References to the European Union in the core curriculum were also made in the context of work and education. Upon completion of a history course:

students shall be familiar with the terms on which young Poles may study in the European Union, and seek information on this issue with regard to other member states. They shall also be able to discuss the general principles of working and establishing a businesses within the European Union (based on information from the Internet, and prepare a Europass-CV. (Podstawa programowa kształcenia ogólnego z komentarzem. Szkoła podstawowa. Historia, 2017, p. 95)

These core curricula clearly differ from one another in terms of the knowledge and competences they require regarding EU history and structures, as well as the duties and benefits entailed by Poland's membership in the European Community. Exposing or ignoring specific issues related thereto may affect students' total vision of Poland's history and its relations with neighboring states. What is more, this may involve invocation of Poland's most distant past, and presentation of its neighboring relations according to the modern political line (Wojdon, 2017). This mechanism was indicated by Mariusz Menz, who in the article Historia szkolna jako dyskurs władzy (2015) shows that history education depends on the political contexts that shape interpretations and explanations thereof. Menz shows how the Baptism of Mieszko I was interpreted in textbooks from the 1980s as an anti-German gesture, as it was deliberately received from the Czechs in order to avoid the (alleged) mediation of the German Reich. Since Poland's accession to the European Union, school textbooks have interpreted it differently, i.e. as the event that brought Poland into Europe (Menz, 2015, p. 284). Given the country's modern historical policy (Osiński, 2012, pp. 37-52), further reinterpretation of the event is expected. This position is supported by Jerzy Szacki, who in consideration of the past stressed that:

The past itself does not provide any clear models worth following. Traditions are "discovered" only as a result of the complicated processes of memorizing and forgetting, accepting and rejecting, affirming and negotiating and even simply fabrication; as well as frequent attempts to establish processes, made most often not by those who really know what happened, but by researchers of modern society, which is subject to the constant changes of culture and politics. (Szacki, 2001, p. 25)

The new theoretical development of contexts and historical events, as well as criticism of current historical research, sheds new light on the past. However, the constant reworking of tradition mentioned by Szacki does not result from the needs of individuals 
to redefine the past, but from changes in the social, economic, media and political discourses that shape education within the meaning of Michael Foucault's governmentality (Kaščák \& Pupala, 2011). To paraphrase Hayden White, history, as a subject in schools, is accessible through language and narration practices; and our experience of history is inseparably connected with historical discourse. Indeed, "history is not only a subject of study, but also-and maybe even primarily - a certain attitude towards the 'past' that is possible only through a special type of written discourse (White, 2009, p. 21). Historical literature therefore becomes the carrier of certain discourses, whose analysis allows us to reconstruct a vision of history. The histories included in school textbooks are not objective narrations of the past, but stories on diversification and unity, conflicts, truces, wars and alliances, specific figures and their impact on the course of events. These stories are built on concepts and metaphors whose discovery and analysis reveal specific networks of beliefs that impact both the reception of historical narrations, and the perception and conceptualization of modern phenomena and socio-cultural practices. In other words, the method according to which we are taught to interpret and understand events from the past has a clear influence on the interpretative practices we use to assess contemporary events.

An opportunity to reconstruct missing links in the knowledge imparted through Polish education is an awareness of the multiple discourses and socio-cultural practices that form and historicize our reality. School textbooks should refer to multiple texts in the contexts of different groups and minorities who are underrepresented in the educational space. The images thereof are currently tailored to fit into the dominant narrative of the Polish nation and Polish culture. The numerous narrations (including those of minority groups) in literature, art, film, music and architecture offer different articulations of their experiences, everyday practices and value systems, which are worth individual treatment as part of Polish history.

Finally, we should recall the opinion of Jeromy Bruner (2006), who stated that education is not an island, but part of a cultural continent. In order to create an open society, it should harness the inherent potential of criticism, and unmask inequality, oppression, hidden agendas, secret knowledge and specific ideologies which through their transparency operate as norms that preserve the social status quo. Socio-cultural anthropologythanks to its egalitarianism, focus on concrete cultural phenomena, research model, and ability to unveil abuses dominating cultural, social and political arenas-can help create a society that is democratic and open according to Popper's definition; that does not aim to homogenize worldviews, lifestyles, values or socio-cultural practices, but to build the peaceful coexistence of all citizens. This seems especially important in a situation where modern education policy (both globally and locally) is oriented not so much towards the formation of an open society, but a dangerously closed national society focused on its own traditions, cultural heritage and glorified history.

From the anthropological perspective, equality policy and the opening up of educational practices can revive the humanities and overcome their focus on an ethnocentrically understood national culture in favor of a focus on current processes and everyday socio -cultural situations. One of the basic goals of education should be to construe the humanities as a fundament to democracy, which, according to Martha Nussbaum, requires that citizens possess "the ability to think critically," "the ability to see beyond local conditions," "the ability to handle global issues from the perspective of a world citizen" and "the ability to empathize with the attitudes of others" (Nussbaum, 2010, p. 7). 
An open society, as postulated by K. Popper, can only be shaped with the support of an education system that corrects ignorance and stereotyping, and builds bridges between the known and unknown. The strategy of multiplying perspectives and languages for description of reality allows us to dismantle the utopia of universalism that forms a society of seeming consensus, but that reality dampens and silences its natural diversification. These realizations question the openness of Polish education policy to issues that are the condition of self-knowledge by way of confronting what is different. With respect to the discussion on an open society, it is worth invoking David Richards (1989), who emphasizes a need for "the principle of tolerance" for natural cultural multiplicity. Based on this principle, he says, constitutional systems reconcile citizens' conflicting interests with their interpretive claims.

\section{REFERENCES}

Abramowicz, M. (Ed.). (2011). Wielka nieobecna—o edukacji antydyskryminacyjnej w systemie edukacji formalnej w Polsce. Warszawa: Towarzystwo Edukacji Antydyskryminacyjnej.

Archer, M. (2000). Being human: The problem of agency. Cambridge: Cambridge University Press. https://doi.org/10.1017/CBO9780511488733

Bruner, J. (2006). Kultura edukacji (T. Brzostowska-Tereszkiewicz, Trans.). Kraków: Universitas.

Carretero, M. (2011). Constructing patriotism: Teaching history and memories in global worlds. Charlotte, NC: Information Age Publishing.

Červinková, H., \& Gołębniak, B. D. (Eds.). (2010). Badania w działaniu: Pedagogika i antropologia zaangażowane. Wrocław: Wydawnictwo Naukowe Dolnośląskiej Szkoły Wyższej.

Chomczyńska-Rubacha, M. (Ed.). (2011). Podręczniki i poradniki: Konteksty. Dyskursy. Perspektywy. Kraków: Wydawnictwo Impuls.

Chrzanowska, I., Jachimczak, B., \& Pawelczak, K. (Eds.). (2013). Miejsce Innego we wspótczesnych naukach o wychowaniu-w poszukiwaniu pozytywów. Poznań: Wydawnictwo Uniwersytetu im. Adama Mickiewicza w Poznaniu.

Chustecka, M., Kielak, E., \& Rawłuszko, M. (Eds.). (2016). Edukacja antydyskryminacyjna: Ostatni dzwonek! O deficytach systemu edukacji formalnej w obszarze przeciwdziałania dyskryminacji i przemocy motywowanej uprzedzeniami: Raport z badań. Warszawa: Towarzystwo Edukacji Antydyskryminacyjnej.

Deklaracja europejskich ministrów edukacji na temat edukacji międzykulturowej w nowym kontekście europejskim (Declaration of European Ministers of Education on Multicultural Education on the Context of Europe). (n.d.). Retrieved December 15, 2012, from http://archiwum.men.gov.pl

Derrida, J. (2015). Uniwersytet bezwarunkowy (K. M. Jaksender, Trans.). Kraków: Wydawnictwo Eperons Ostrogi.

Dobra szkoła. Reforma edukacji. Najważniejsze zmiany. Pytania i odpowiedzi. (2017). Retrieved May 23, 2017, from http://reformaedukacji.men.gov.pl

Domańska, E. (2007). "Zwrot performatywny" we współczesnej humanistyce. Teksty Drugie, 2007(2), 48-61. 
Frączak, Z. (2004). Oświata polska wobec perspektyw globalizacji oświatowej. In A. Śniegulska (Ed.), Reforma oświatowa wobec wiedzy pedagogicznej (pp. 36-49). Rzeszów: Uniwersytet Rzeszowski.

Ghandi, L. (2008). Teoria postkolonialna. Wprowadzenie krytyczne (J. Serwański, Trans.). Poznań: Wydawnictwo Poznańskie.

Jaskułowski, K., Majewski, P., \& Surmiak, A. (2018). Teaching the nation: History and nationalism in Polish school history education. British Journal of Sociology of Education, 39(1), 77-91. https://doi.org/10.1080/01425692.2017.1304205

Kaniowska, K. (2009). Heurystyczna wartość wiedzy antropologicznej. In A. Pomieciński, \& S. Sikora (Eds.). Zanikające granice: Antropologizacja nauki i jej dyskursów (pp. 1942). Poznań: Biblioteka Telgte.

Kaščák, O., \& Pupala, B. (2011). Governmentality-Neoliberalism-Education: The risk perspective. Journal of Pedagogy, 2(2), 145-160. https://doi.org/10.2478/v10159-011-0007-z

Kraśniewski, A. (2009). Proces Boloński: To już 10 lat. Warszawa: Fundacja Rozwoju Systemu Edukacji.

Lee, P. (2011). Series introduction. In M. Carretero, M. Asensio, \& M. Rodríguez Moneo (Eds.), History education and construction of national identities. Charlotte, NC: Information Age Publishing.

Levinson, B., Foley, D., \& Holland, D. (Eds.). (1996). The cultural production of the educated person: Critical ethnographies od schooling and local practice. New York, NY: State University of New York Press.

Majbroda, K. (2011). Dlaczego humanistyka ucieka w antropologię? Kilka uwag o dostrzeżonym eskapizmie. Literatura Ludowa, 2011(2), 3-15.

Majbroda K. (2016). Z odmiennej perspektywy: Współczesna polityka edukacyjna w perspektywie antropologii społeczno-kulturowej. In D. Angutek (Ed.), Przyszłość wielokulturowości w Polsce? Nowe wyzwania dla antropologii kulturowej i etnologii (pp. 41-56). Wrocław: Polskie Towarzystwo Ludoznawcze, Uniwersytet Zielonogórski.

Marcus, G., \& Fischer, M. M. J. (1999). Anthropology as cultural critique: An experimental moment in the human sciences. Chicago, IL: The University of Chicago Press.

Markowski, M. P., \& Nycz, R. (Eds.). (2012). Kulturowa teoria literatury: Główne pojęcia i problemy. Kraków: Wydawnictwo Universitas.

Menz, M. (2015). Historia szkolna jako dyskurs władzy. Środkowoeuropejskie Studia Polityczne, 2015(4), 281-292.

Michałowska, D. A. (2013). Neoliberalizm i jego (nie)etyczne implikacje edukacyjne. Poznań: Wydawnictwo Naukowe UAM.

Nussbaum, M. (2010). Not for profit: Why democracy needs the humanities. Princeton, $\mathrm{NJ}$ : Princeton University Press.

Nycz, R. (2015). Wstęp. In R. Nycz, \& A. Łebkowska (Eds.), Kultura afektu-afekty w kulturze: Humanistyka po zwrocie afektywnym (pp. 7-24). Warszawa: Instytut Badań Literackich PAN.

Osiński, Z. (2012). Współczesna polityka historyczna a edukacyjne wyzwania społeczeństwa informacyjnego i gospodarki opartej na wiedzy. In A. Bieś, M. Chrost, \& B. Topij-Stępińska (Eds.), Pamięć. Historia. Polityka. Kraków: Wydawnictwo WAM. Ośrodek Karta.

Piasek, W. (2011). Historia jako wiedza lokalna: "Antropologiczne przesunięcie" w badaniach nad historiografią PRL. Toruń: Wydawnictwo Naukowe UMK. 
Plumińska-Mieloch, A. (2017). Program nauczania. Historia. Szkoła podstawowa 4-8. Retrieved November 15, 2017, from https://ucze.pl/zasob/program-nauczania-historia-klasy-4-8/

Podstawa programowa kształcenia ogólnego. (2017). Retrieved May 13, 2017, from http://www.dziennikustaw.gov.pl/DU/2017/356

Podstawa programowa kształcenia ogólnego z komentarzem. Geografia. (2017). Retrieved September 10, 2017, from https://men.gov.pl/zycie-szkoly/ksztalcenie-ogolne/podstawa-programowa/podstawa-programowa-materialy-dla-nauczycieli.html

Podstawa programowa kształcenia ogólnego z komentarzem. Szkoła podstawowa. Historia. (2017). Retrieved September 10, 2017, from https://men.gov.pl/zycie-szkoly/ksztalcenie-ogolne/podstawa-programowa/podstawa-programowa-materialy-dla-nauczycieli. html

Podstawa programowa kształcenia ogólnego z komentarzem. Szkoła podstawowa. Wiedza o społeczeństwie. (2017). Retrieved May 23, 2017, from https://men.gov.pl/wp content/uploads/2017/04/wos-lo-zr.pdf

Podstawa programowa z komentarzami: T. 4. Edukacja historyczna i obywatelska w szkole podstawowej, gimnazjum i liceum. (2012). Retrieved November 18, 2017, from http://docplayer.pl/184160-Podstawa-programowa-z-komentarzami-tom-4-edukacjahistoryczna-i-obywatelska-w-szkole-podstawowej-gimnazjum-i-liceum.html

Popper, K. (1993). Spoteczeństwo otwarte i jego wrogowie: T. 1. Urok Platona (K. Krahelska, Trans.). Warszawa: Wydawnictwo Naukowe PWN.

Raport dla UNESCO Międzynarodowej Komisji do spraw Edukacji dla XXI wieku pod przewodnictwem Jacques'a Delorsa "Edukacja: jest w niej ukryty skarb". (1998). Warszawa: Stowarzyszenie Oświatowców Polskich Wydawnictwa UNESCO.

Reason, P., \& Torbert, W. (2010). Zwrot działaniowy: Ku transformacyjnej nauce społecznej. (M. Lavergne, Trans.). In H. Červinková, \& B. D. Gołębniak (Eds.), Badania w działaniu: Pedagogika $i$ antropologia zaangażowane (pp. 117-152). Wrocław: Wydawnictwo Naukowe Dolnośląskiej Szkoły Wyższej.

Richards, D. A. J. (1989). Tolerantion and the Constitution. New York, NY: Oxford University Press.

Spindler, G. D. (1974). Education and cultural process: Toward an anthropology of education. New York, NY: Holt, Rinehrt and Winston.

Spindler, G. D., \& Spindler, L. (1987). Interpretive ethnography of education: At home and abroad. New York, NY: Standford University.

Szacki, J. (2001). Tradycja. Warszawa: Wydawnictwa Uniwersytetu Warszawskiego.

White, H. (2009). Proza historyczna (T. Dobrogoszcz, Trans.). Kraków: Wydawnictwo Universitas.

Wiśniewski, M., Hansen, K., \& Bilewicz, B. (2017). Mowa nienawiści, mowa pogardy: Raport z badania przemocy werbalnej wobec grup mniejszościowych. Retrieved December 6, 2017, from http://www.batory.org.pl/upload/files/pdf/MOWA_NIENAWISCI_MOWA_POGARDY_INTERNET.pdf

Wojdon, J. (2017). Textbooks as propaganda, Poland under Communist rule, 1944-1989. New York, NY: Routledge.

Wolter, E. (2016). “Uczyć się, aby żyć wspólnie” w koncepcji Międzynarodowej Komisji do Spraw Edukacji dla XX wieku. Forum Pedagogiczne, 2016(1), 71-80. 